\title{
Organisational readiness for introducing a performance management system
}

\author{
Authors: \\ Michael Ochurub ${ }^{1}$ \\ Mark Bussin ${ }^{1}$ \\ Xenia Goosen \\ Affiliations: \\ ${ }^{1}$ Department of Industrial \\ Psychology and People \\ Management, University of \\ Johannesburg, South Africa \\ Correspondence to: \\ Mark Bussin \\ Email: \\ drbussin@mweb.co.za \\ Postal address: \\ PO Box 524, Auckland Park \\ 2006, South Africa \\ Dates: \\ Received: 03 June 2011 \\ Accepted: 04 Apr. 2012 \\ Published: 20 Sept. 2012 \\ How to cite this article: \\ Ochurub, M., Bussin \\ M., \& Goosen, X. (2012). \\ Organisational readiness for \\ introducing a performance \\ management system. SA \\ Journal of Human Resource \\ Management/SA Tydskrif vir \\ Menslikehulpbronbestuur, \\ 10(1), Art. \#389, 11 pages. \\ http://dx.doi.org/10.4102/ \\ sajhrm.v10i1.389
}

(C) 2012. The Authors

Licensee: AOSIS

OpenJournals. This work

is licensed under the

Creative Commons

Attribution License.
Orientation: The successful introduction of performance management systems to the public service requires careful measurement of readiness for change.

Research purpose: This study investigated the extent to which employees were ready for change as an indication of whether their organisation was ready to introduce a performance management system (PMS).

Motivation for the study: Introducing system changes in organisations depends on positive employee preconditions. There is some debate over whether organisations can facilitate these preconditions. This research investigates change readiness linked to the introduction of a PMS in a public sector organisation. The results add to the growing literature on levels of change readiness.

Research design, approach and method: The researchers used a quantitative, questionnairebased design. Because the organisation was large, the researchers used stratified sampling to select a sample from each population stratum. The sample size was 460 , which constituted $26 \%$ of the total population. They used a South African change readiness questionnaire to elicit employee perceptions and opinions.

Main findings: The researchers found that the organisation was not ready to introduce a PMS. The study identified various challenges and key factors that were negatively affecting the introduction of a PMS.

Practical/managerial implications: The intention to develop and introduce performance management systems is generally to change the attitudes, values and approaches of managers and employees to the new strategies, processes and plans to improve productivity and performance. However, pre-existing conditions and attitudes could have an effect. It is essential to ensure that organisations are ready to introduce performance management systems and to provide sound change leadership to drive the process effectively. This study contributes to the body of knowledge about the challenges and factors organisations should consider when they introduce performance management systems.

Contribution/value-add: This research adds to the knowledge about aspects of change readiness, change management and introducing change initiatives.

\section{Introduction}

\section{Key focus of the study}

A growing body of research reveals that systematic and thorough workplace diagnosis and documents will provide the real basis for improving performance at organisational, process and worker levels (Swanson, 1996). The council of the organisation the researchers selected for this research realised that it was necessary to improve its efficiency and effectiveness in delivering services and hoped to change fundamentally how its organisation operated. To improve efficiency and effectiveness, the council thought that it was essential that the organisation was ready to ensure the successful introduction of change initiatives.

An assessment of organisational readiness should lead to the development of a model of the preconditions necessary to introduce performance management systems appropriately to organisations, with greater emphasis on employee buy-in, involvement in the process and proper communication of the change process (Karve, 2009).

All the previous attempts to design and introduce a performance management system (PMS) to the organisation had failed. Therefore, the key focus of this study was to conduct a diagnosis to determine the readiness of the organisation to introduce one. 


\section{Background to the study}

The researchers conducted this study in a large public organisation in Namibia. Before 1998, the organisation had a performance appraisal (measurement) system in place. The organisation used it to measure staff performance annually.

The system had weaknesses because it did not set performance standards and was very open to bias, nepotism and favouritism during the performance appraisal process. As a result, the organisation suspended the performance appraisal system in 1998. Since then, the organisation has not introduced an institutional mechanism to improve, measure, monitor or evaluate its staff and the performance of the organisation.

All municipalities are subject to administrative and operational changes to improve their performance and productivity, as well as to achieve broader organisational objectives (Kok, 2007). In a response to the lack of a PMS, the city council decided to design and introduce a functioning PMS as part of a change process.

The present research aimed to investigate the level of readiness of the organisation to introduce a PMS. The rationale for this is that organisations cannot introduce performance management systems successfully without the buy-in and involvement of all employees and a strategy to develop human resources so that everyone has a clear understanding of the change initiatives and their benefits to employees and their organisations.

Therefore, it is crucial to unearth the key factors or preconditions for introducing performance management systems and to determine and evaluate the attitudes and feelings of employees about doing so.

\section{Research objectives}

The aim of this study was to report the results of the organisational diagnosis the researchers conducted to determine the readiness of the organisation to introduce a PMS. The primary objective was to determine the levels of change readiness that might affect its introduction. The secondary objective was to determine the challenges and factors that would probably accompany introducing a PMS.

\section{Trends from the research literature}

Organisations operate in complex and changing environments. They grow in productivity, activities and profitability, which pose greater challenges to them and require changes in the way they operate (Carnall, 2007). All these challenges and increasing demands from external environments might mean that they have to cultivate a performance- and achievement-orientated culture (Armstrong, 2006; Kaplan \& Norton, 1996; Kates, Marconi \& Mannle Jr., 2001; Swanson, 1996). Introducing a PMS to an organisation is a strategic change and one of the most fundamental ways of improving productivity, efficiency and effectiveness and, ultimately, increasing revenue (Nelongo, 2011).
Change readiness is the best early indicator of what lies ahead. The scars that successful and unsuccessful initiatives have left are others (Bridges, 2010). The key to change readiness is whether the employees are ready to do their jobs in new environments (Madsen, Miller \& John, 2005). Introducing performance management systems as change initiatives is pivotal to the strategies of organisations and they should ensure organisational readiness before doing so (Canterucci, 2008). When organisational readiness for change is high, the employees are more likely to initiate change, exert greater effort, show greater persistence and display more cooperative behaviour (Armenakis \& Harris, 2002).

All over the world, local governments are under pressure to modernise, transform and become accountable to their communities. One way they are achieving this is by introducing performance management systems (Williams, 2006). However, implementing these systems requires change and the success of these changes depends on the readiness of the organisations.

Organisations need to manage change in order to reduce resistance to it by, for example, introducing performance management systems. Change management coordinates a transition to achieve lasting change in organisations (Jones, Jimmieson \& Griffiths, 2005). Organisations often present it as a process and use tools and techniques to manage people in order to achieve the required business outcomes (Nickols, 2006; Robbins, Odendaal \& Roodt, 2003). A key starting point is to determine when organisations are ready to change.

Change readiness includes the management strategies that organisations use to address any resistance in their workforces to the new initiatives (Stratman, 2002). Organisations' readiness for change depends on the level of employees' commitment to the change and whether they believe the change can happen (Weiner, 2009).

\section{Performance management systems}

Managing performance is essential for any organisation. It creates a framework that offers encouragement, support and guidance and helps to establish a performance-orientated culture (Dixon, 2004; Walters, 1995). Olve, Roy and Wetter (2004) argue that performance management systems create organisational cultures of personal responsibility for business and personal improvement. Other research has argued that a PMS improves service delivery through a culture of performance dialogue, improves performance against specific organisational goals, improves employees' understanding of the link between performance and organisational goals and leads to positive behaviour to achieve them (Armstrong, 2006; DeCenzo \& Robbins, 2005; Dixon, 2004; Hale, 2004; Kates et al., 2001; Poister, 2003; WorldatWork, 2006).

However, these writers assume that a PMS is already in place or that is an acceptable innovation to the organisation. Being able to develop a PMS has its own challenges and cultural resistance. 
Organisations need to be ready for the change and need to manage the change to performance management systems. Robbins et al. (2003) argue that employees may feel threatened, in terms of their interests and job security, if organisations just introduce new performance management systems. On a systemic level, it is important that one recognises that organisations need to be ready for the new system. This includes the fact that employees need to understand what their organisations will achieve by introducing performance management systems, why they need the systems, how they will implement the changes and who will drive them (Robbins et al., 2003).

\section{The importance of change readiness when introducing a new business system}

Change readiness is the best early indicator of how organisations will respond to the introduction of new business systems, like performance management systems. The types of performance systems that organisations have tried in the past will affect the responses. Therefore, it is crucial that change agents, and those who drive change initiatives in organisations, should consider the extent to which employees are committed to the change and whether they believe that their organisations are able to change (Weiner, 2009).

When organisational readiness for change is high, employees are more likely to be part of the change process (Armenakis \& Harris, 2002; Madsen et al., 2005). On the other hand, when organisational readiness for change is low or nonexistent, employees are likely to resist the change, put less effort into its implementation and persevere less in the face of implementation challenges (Weiner, Amick \& Lee, 2008). Therefore, it is essential for managers to investigate the level of change readiness of their organisations before introducing new systems. Failure to do so may result in wasted finances and resources on systems that employees do not accept and may undermine.

Van Tonder (2004) argues that organisations need to identify and analyse their 'self-concepts', or the views they have of themselves. They should also analyse how other stakeholders see them (Bacal, 2007; Rogan, 2002). Other features of successful change in organisations include having clear change architectures (Bunker \& Alban, 1996; Carnall, 2007; Jacobs, 1994), the buy-in and acceptance of stakeholders (Keet, 2005), clear overviews of the goals and directions of the change processes and the roles people will play (Hale, 2004). It is also essential to be open to hearing frustrations, engaging in dialogue and managing expectations (Ainsworth, Smith \& Miller, 2002). Leaders must create a sense of urgency in their organisations, build teams that can guide the change processes, continually communicate the need for change and then empower people to carry out the required change efforts (Allio, 2005; Amanto, 2009; Bennis, 2006; Stensgaard, 2007). Poor leadership during the change process can mean that organisations become dysfunctional (Stacey, 2003).

Jones et al. (2005) assessed the effects of change readiness about introducing a new computer system to a state department.
The authors found that readiness for change was associated with a positive organisational culture. This readiness was also associated with the successful introduction of the system.

Interestingly, attempts to develop change readiness cultures may not lead to successful introductions of new systems. Abdinnour-Helm, Lengnick-Hall and LengnickHall (2003) investigated a programme to develop positive pre-implementation attitudes about an enterprise resource planning system. The authors found that length of time with the firm and position had a bigger effect on acceptance of the system than did any attempt to develop positive attitudes beforehand.

\section{Pre-conditions and key factors to consider before introducing performance management systems}

Certain pre-conditions need to exist before organisations introduce performance management systems. Managers must mobilise their organisations, communicate the roles and responsibilities of those involved in the change processes and ensure that the processes are inclusive, participatory, transparent, simple, realistic, fair, objective, developmental and non-punitive (Amatayakul, 2005; Hardison, 1998; Kok, 2007; O'Connor \& Fiol, 2006; Walters, 1995; Williams, 2002).

Canterucci (2008) argues that performance management systems, as change initiatives, are pivotal to the strategies of organisations and they should ensure that they are ready. D'Ambrosio (2007) proposed that organisations should structure the planning to include logical thought processes that will address the external and internal environments and look at the past, present and future.

In the current research, the managers of the organisation felt that the changing internal and external environments (social, political, technological and competitive) made it essential to develop a PMS (Costello, 1994; Weiss \& Hartle, 1997; Williams, 2002).

\section{Statement of the problem and specific research objectives}

The council of the organisation became increasingly concerned about the quality of service it was delivering to its clients. However, they were also aware that it is difficult to measure and address the performance of staff members properly without a well-designed and successful PMS. The question was whether the organisation was ready to introduce a PMS. In addition, the organisation needed to identify what factors it should consider before doing so, and to determine the attitudes and feelings of employees about introducing a PMS.

The current study aimed to determine the key factors or pre-conditions for introducing a PMS in order to ensure successful implementation. The researchers also determined and evaluated the attitudes and feelings of the employees about a PMS. 


\section{The potential value of the study}

This research contributes to the theoretical knowledge of change readiness by expanding the body of knowledge about the readiness of organisations before introducing performance management systems. Therefore, various employers in the public sector can use this study to prepare their organisations for change and the successful introduction of change initiatives.

The findings of this study will influence the decision-making processes about introducing a PMS effectively as part of a change process for the selected organisation. It will also serve as a guideline for determining the change readiness of other municipalities.

\section{Research design \\ Research approach}

The researchers used a questionnaire-based, quantitative design (Kuhn, 2009). They used a South African inventory to assess employees' perceptions about an organisation's readiness for introducing a PMS.

\section{Research method}

\section{Research participants}

The organisation had 1740 employees (see Table 1). The researchers used stratified random sampling to select a separate simple random sample from each population stratum (Levy \& Lemeshow, 2011).

There were ten departments in the organisation:

- Office of the Chief Executive Officer

- Finance

- Transportation

- City Police and Emergency Management Services

- Economic and Community Development

- Planning, Urbanisation and Environment

- Infrastructure and Waste Management

- Information Communication and Technology

- Electricity

- Human Resources.

There were seven groups, or strata, of employees in these departments (see Table 1):

- strategic executives

- middle managers

- supervisors or specialists

- skilled workers

- semi-skilled workers

- unskilled workers

- contract workers (Hitchcock \& Hughes, 1995; Parsons, 1984; Salant \& Dillman, 1994).

The researchers defined the study population and then determined the sample size. Given the questionnaire and nature of the questionnaire, they regarded a sample of more than $20 \%$ as appropriate (Salant \& Dillman, 1994).

The researchers distributed questionnaires to 460 employees. They included 300 (65.2\%) semi-skilled and unskilled
TABLE 1: Total number of employees.

\begin{tabular}{llll}
\hline Level & Men & Women & Total \\
\hline Chief Executive Officer & 1 & 0 & 1 \\
Senior management (strategic executives) (E-band) & 7 & 2 & 9 \\
Middle management (divisional heads) (D-band) & 30 & 8 & 38 \\
Specialised or senior supervisory (C-band) & 35 & 16 & 51 \\
Skilled (C-band) & 325 & 156 & 481 \\
Semi-skilled (B-band) & 584 & 230 & 814 \\
Unskilled (A-band) & 281 & 37 & 318 \\
Temporary or contracts & 12 & 16 & 28 \\
\hline Total & $\mathbf{1 2 7 5}$ & $\mathbf{4 6 5}$ & $\mathbf{1 7 4 0}$ \\
\hline
\end{tabular}

employees at A-B bands, 155 (33.7\%) skilled employees at E-C bands and five (1.1\%) employees who had contracts. This final sample constituted $26 \%$ of the total population. The stratified random sampling technique meant that every employee in each stratum had an equal chance of selection and ensured a representative sample of the population (Plant \& Douglas, 2006). However, employees completed and returned only 432 questionnaires. This number constitutes $25 \%$ of the total population.

\section{Measuring instruments}

The researchers chose the Change Readiness Inventory (CRI), which Roodt and Kinnear (2007) designed, to develop the questionnaire for the study.

The CRI uses an integrated theoretical model of inertiarelated concepts or inertia contributory factors that numerous authors have identified (Roodt \& Kinnear, 2007). The CRI enables users to identify a number of specific organisational change facilitating or inhibiting factors, which they can group into two broad categories: transformational and transactional variables.

The questionnaire for the study consisted of five questions based on biographical information and used 58 multiplechoice questions. All the questions in sections 2-13 came from the CRI, which its designers developed strictly for use in an organisational (corporate) setting for research and for diagnostic (consulting) purposes (Roodt \& Kinnear, 2007).

Given that the questionnaire has a corporate and consulting slant, not all questions applied to a parastatal. The researchers excluded these questions. They acknowledge that this could affect the reliability of the questionnaire.

An example of the scale is shown in Table 2.

\section{Reliability of the Change Readiness Inventory instrument}

Van Rooyen (2007) reports a Cronbach alpha (internal consistency) of .98 on the inertia scale and .89 on the 'external change forces, change strategy and imposed personal demands' scale of the CRI. These figures come from an initial study that Roodt and Kinnear (2007) conducted on 617 employees from junior to senior management in different industries.

Other researchers report similar reliability scores. For example, researchers found a Cronbach's alpha of .99 in a 
TABLE 2: Example of the scale used.

\begin{tabular}{lll}
\hline Number & $\begin{array}{l}\text { Questions (please indicate the extent to which you agree or disagree with each of these statements by } \\
\text { placing an X in the appropriate space to indicate your view) }\end{array}$ & DN \\
\hline 2.1 & Do you understand the purpose of implementing the performance management system? \\
2.2 & Are you familiar with the content of a performance management system? \\
2.3 & Do you know what your role is in implementing the performance management system? \\
2.4 & Does the company have a specific strategy to manage the sources of resistance to change? \\
\hline
\end{tabular}

DN, definitely not; $N$, no; $U$, uncertain; $Y$, yes; YD, yes definitely.

TABLE 3a: Gender distribution of respondents, number of respondents from each department and job levels.

\begin{tabular}{|c|c|c|c|c|c|c|c|c|c|c|c|}
\hline \multirow[t]{2}{*}{ Department } & \multicolumn{3}{|c|}{ Gender } & \multirow[t]{2}{*}{ RES } & \multicolumn{7}{|c|}{ Job levels } \\
\hline & Men & Women & Total & & SE & MM & SS & SK & SSK & USK & CON \\
\hline Economic and Community Development Services & 27 & 13 & 40 & 46 & 1 & 2 & 3 & 19 & 22 & 21 & 2 \\
\hline City Police and Emergency Management & 31 & 11 & 42 & 45 & - & 1 & 3 & 15 & 17 & 18 & - \\
\hline Human Resources & 32 & 11 & 43 & 22 & - & 2 & - & 17 & 20 & 21 & - \\
\hline Planning, Urbanisation and Environment & 30 & 16 & 46 & 55 & 1 & 1 & 2 & 9 & 11 & 10 & 1 \\
\hline Transportation & 31 & 13 & 44 & 55 & 1 & 2 & - & 21 & 24 & 23 & 1 \\
\hline Office of the Chief Executive Officer & 25 & 14 & 39 & 48 & - & 1 & - & 3 & 5 & 4 & - \\
\hline Infrastructural and Waste Management & 35 & 12 & 47 & 55 & 1 & 1 & 1 & 8 & 11 & 13 & 1 \\
\hline Information Communication and Technology & 34 & 8 & 42 & 18 & - & 1 & - & 5 & 7 & 5 & - \\
\hline Finance & 28 & 12 & 40 & 44 & 1 & 1 & - & 9 & 11 & 13 & - \\
\hline Electricity & 36 & 5 & 41 & 44 & - & 1 & 3 & 11 & 13 & 11 & - \\
\hline Total & 309 & 115 & 424 & 432 & 5 & 13 & 12 & 117 & 141 & 139 & 5 \\
\hline
\end{tabular}

RES, number of respondents; SE, strategic executives; MM, middle management; SS, supervisor or specialists; SK, skilled staff; SSK, semi-skilled; USK, unskilled staff; CON, temporary staff on contracts.

group of 340 managers in Australia and a Cronbach's alpha of .78 for a group of 347 trainees who worked for a state organisation. The internal consistency reliabilities for the twelve dimensions varied between .677 and .896 with only two reliabilities below 80 (Van Rooyen, 2007).

\section{Validity of the Change Readiness Inventory instrument}

Van Rooyen (2007) argued that the process followed in constructing the questionnaire was consistent with the generally accepted test construction procedures that Schepers (1992) and Foxcroft (2005) suggested. This ensured that the questionnaire would have content validity with a high degree of face validity. The factor analytical procedures that iterative item reliability analyses follow shows that the instrument also has structural validity (factorial validity) based on the first robust factor extracted in the reported studies. Van Rooyen (2007) maintains that high item-total score correlations also show that the items measure the same larger construct, namely organisational change readiness or inertia.

\section{Research procedure}

The researchers distributed 155 (33.7\%) questionnaires via email to the strategic executives, the divisional or sectional heads and employees in the $\mathrm{C}$ bands as well as five $(1.1 \%)$ questionnaires to employees on contract. They arranged with the divisional or sectional heads and other supervisors to meet $300(65.2 \%)$ semi-skilled and unskilled employees during lunch or after working hours in the boardroom. They reviewed all the questions with the participants to ensure that they understood them. The employees completed and returned the questionnaires immediately after they had completed them.

The researchers allowed some participants $(10 \%)$, who needed more time to think about specific questions, to take questionnaires home and complete them at their own pace, as Munn and Drever (1995) suggested. These participants returned the completed questionnaires the next day via their divisional heads and supervisors.

\section{Statistical analysis}

The researchers analysed the questionnaires using descriptive statistics. The researchers explored and presented the individual variables to show specific values, to show the highest and lowest values, trends, proportions and distribution values (Saunders, Lewis \& Thornhill, 2003). They compared the variables to show specific values and interdependence as well as the trends and proportions (Cohen, Manion \& Morrison, 2000).

\section{Results}

A synopsis of the biographical data is reflected in Table 3. Table 3 also shows that 432 employees completed the questionnaire. However, only 424 respondents indicated their genders. The number of respondents the researchers selected from each department varies according to its size. The table also categorises the different job levels into strategic executives (SE), middle management (MM), supervisors or specialists (SS), skilled staff (SK), semi-skilled staff (SSK), unskilled staff (USK), and temporary staff on contracts (CON)

\begin{tabular}{ll} 
TABLE 3b: The respondents' number of years worked for the organisation. \\
\hline Years & Total \\
\hline 1 & 16 \\
2 & 139 \\
3 & 228 \\
4 & 26 \\
5 & 18 \\
$6+$ & 1 \\
\hline
\end{tabular}


and gives the number of respondents in each category. Most of the respondents had worked for the organisation for more than two or three years.

\section{Clear communication of purpose}

The responses related to clear communication of purpose and understanding of the purpose of a PMS is given in Table 4 . The results show that $46.9 \%$ of respondents did not understand the purpose of introducing a PMS. In addition, $46.4 \%$ of the participants were not familiar with the content of a PMS. Respondents attribute the failure to introduce a PMS to a poor work climate, poor communication, negative personal images, poor change leadership and no buy-in or support from employees.

\section{Clear vision and commitment}

The respondents' responses to questions about a vision and commitment are given in Table 5. The results suggest that participants did not believe that the top managers had a clear vision of the proposed change. Employees did not have confidence in the ability of the top managers to manage the implementation of change initiatives. The participants also indicated that the top managers did not show commitment to the change initiatives and that they did not always communicate the proposed initiatives to the employees.

\section{Working environment}

Respondents' responses related to the work environment are given in Table 6. Participants indicated that the working environment was not conducive to making suggestions for improvement and that there was uncertainty about whether the organisation considered the ideas of employees for change initiatives. Of the participants, 58\% indicated that the employees were not encouraged to make suggestions about introducing a PMS. Most of the respondents $(68 \%)$ indicated that employees in their respective work units did not encourage each other to support the change processes because they did not see them as positive. They also believed it would not be easy for people to make changes to the content of their jobs once the organisation introduced the PMS.

\section{Training}

Respondents' responses relating to training are given in Table 7. The results show that the most significant problem was that employees do not receive training to cope with new job requirements and that they fear that they will not cope

TABLE 4: Clear communication of purpose.

\begin{tabular}{|c|c|c|c|c|c|c|c|}
\hline Question & Response rate & DN & $\mathbf{N}$ & UC & $\mathrm{Y}$ & YD & Total \\
\hline \multirow[t]{2}{*}{ Do you understand the purpose of implementing a PMS? } & Count & 94 & 103 & 86 & 107 & 39 & 429 \\
\hline & Column percentage & 21.9 & 24.0 & 20.1 & 24.9 & 9.1 & 100 \\
\hline \multirow[t]{2}{*}{ Are you familiar with the content of a PMS? } & Count & 19 & 180 & 84 & 118 & 28 & 429 \\
\hline & Column percentage & 4.4 & 42.0 & 19.6 & 27.5 & 6.5 & 100 \\
\hline \multirow{2}{*}{$\begin{array}{l}\text { Do people in your work unit encourage each other to support } \\
\text { the change initiatives within the organisation such as the } \\
\text { implementation of a PMS? }\end{array}$} & Count & 70 & 222 & 62 & 61 & 14 & 429 \\
\hline & Column percentage & 16.3 & 51.7 & 14.5 & 14.2 & 3.3 & 100 \\
\hline \multirow[t]{2}{*}{ Are people looking forward to the implementation of a PMS? } & Count & 112 & 144 & 105 & 53 & 12 & 426 \\
\hline & Column percentage & 26.3 & 33.8 & 24.7 & 12.4 & 2.8 & 100 \\
\hline
\end{tabular}

PMS, Performance Management System; DN, definitely not; N, no; UC, uncertain; $Y$, yes; YD, yes definitely.

TABLE 5: Clear vision and commitment.

\begin{tabular}{|c|c|c|c|c|c|c|c|}
\hline Question & Response rate & DN & $\mathbf{N}$ & UC & $\mathbf{Y}$ & YD & Total \\
\hline \multirow{2}{*}{$\begin{array}{l}\text { Does the top management have a clear vision of the change to } \\
\text { be made e.g. implementation of a PMS? }\end{array}$} & Count & 124 & 152 & 80 & 57 & 9 & 422 \\
\hline & Column percentage & 29.4 & 36.0 & 19.0 & 13.5 & 2.1 & 100 \\
\hline \multirow{2}{*}{$\begin{array}{l}\text { Do employees have confidence in top management's ability to } \\
\text { manage implementation of change initiatives? }\end{array}$} & Count & 52 & 199 & 123 & 42 & 9 & 425 \\
\hline & Column percentage & 12.2 & 46.8 & 29.0 & 9.9 & 2.1 & 100 \\
\hline \multirow{2}{*}{$\begin{array}{l}\text { Does the top management always communicate the } \\
\text { implementation change initiatives with the employees? }\end{array}$} & Count & 77 & 170 & 104 & 61 & 13 & 425 \\
\hline & Column percentage & 18.1 & 40.0 & 24.5 & 14.4 & 3.0 & 100 \\
\hline
\end{tabular}

PMS, Performance Management System; DN, definitely not; N, no; UC, uncertain; $Y$, yes; YD, yes definitely.

TABLE 6: Work environment in the organisation.

\begin{tabular}{|c|c|c|c|c|c|c|c|}
\hline Question & Response rate & DN & $\mathbf{N}$ & UC & $\mathrm{Y}$ & YD & Total \\
\hline \multirow{2}{*}{$\begin{array}{l}\text { Is the working environment safe for making suggestions for } \\
\text { improvements? }\end{array}$} & Count & 79 & 132 & 140 & 65 & 13 & 429 \\
\hline & Column percentage & 18.4 & 30.8 & 32.6 & 15.2 & 3.0 & 100 \\
\hline \multirow{2}{*}{$\begin{array}{l}\text { Are the employees new ideas considered for implementation of } \\
\text { any change initiatives? }\end{array}$} & Count & 48 & 123 & 210 & 36 & 12 & 429 \\
\hline & Column percentage & 11.2 & 28.7 & 48.9 & 8.4 & 2.8 & 100 \\
\hline \multirow{2}{*}{$\begin{array}{l}\text { Are the employees encouraged to make suggestions regarding } \\
\text { the implementation of a PMS? }\end{array}$} & Count & 71 & 177 & 115 & 53 & 12 & 428 \\
\hline & Column percentage & 16.6 & 41.4 & 26.8 & 12.4 & 2.8 & 100 \\
\hline \multirow{2}{*}{$\begin{array}{l}\text { Do people in your work unit encourage each other to support } \\
\text { the change initiatives in the organisation such as the } \\
\text { implementation of a PMS? }\end{array}$} & Count & 70 & 222 & 62 & 61 & 14 & 429 \\
\hline & Column percentage & 16.3 & 51.7 & 14.5 & 14.2 & 3.3 & 100 \\
\hline \multirow{2}{*}{$\begin{array}{l}\text { Will it be easy for people to make changes to the content of } \\
\text { their jobs, when a PMS is implemented? }\end{array}$} & Count & 123 & 193 & 59 & 42 & 9 & 426 \\
\hline & Column percentage & 28.9 & 45.3 & 13.8 & 9.9 & 2.1 & 100 \\
\hline
\end{tabular}

PMS, Performance Management System; DN, definitely not; N, no; UC, uncertain; $Y$, yes; YD, yes definitely. 
with increased job variety. Most of the respondents (58.9\%) felt that the change would not bring about new challenges in employees' jobs.

\section{Organisational structure and policies}

The respondents' responses that relate to organisational structure and policies are given in Table 8 . The respondents revealed the weakness of the organisation's structure because $41.9 \%$ of the respondents stated that the structure of the organisation was not conducive for introducing a PMS. Of the participants, $38.2 \%$ stated that they were uncertain, whereas the remaining $19.9 \%$ participants indicated that the structure was conducive for introducing a PMS.

\section{Change leadership and interventions}

The responses relating to change leadership and interventions are given in Table 9. The respondents indicated that:

- the most influential people in the organisation did not champion the introduction of change initiatives

- the organisation did not always plan the change initiatives well

- the organisation did not consider all the components of the business when it planned the change initiatives

- the organisation did not involve the employees, who are affected by change, in drafting the change plans.
These responses could explain why employees were not committed to change initiatives in the organisation.

\section{Attitudes and feelings about introducing a performance management system}

Respondents' attitudes and feelings about introducing a PMS are given in Table 10. The findings show that employees would not commit to achieving the objectives of a PMS and that they did not believe that introducing a PMS would improve the performance of the organisation. Most respondents did not believe that introducing a PMS would have a positive effect on their earnings and they were not sure whether introducing a PMS would improve the relationships between staff members and their supervisors. Respondents did not see introducing a PMS as fair to employees. Instead, they saw it as an additional stress factor at work.

\section{Willingness of employees to be part of a change process}

The responses relating to the willingness of employees to be part of a change process are given in Table 11. Most respondents indicated that they:

- would willingly choose to be a part of a change process $(79.5 \%)$

- were likely to change the way they work because of the change process $(71.9 \%)$

TABLE 7: Training provided by organisation

\begin{tabular}{|c|c|c|c|c|c|c|c|}
\hline Question & Response rate & DN & $\mathbf{N}$ & UC & $\mathbf{Y}$ & YD & Total \\
\hline \multirow{2}{*}{$\begin{array}{l}\text { Do people receive training to cope with their new job } \\
\text { requirements? }\end{array}$} & Count & 40 & 165 & 166 & 39 & 16 & 426 \\
\hline & Column percentage & 9.4 & 38.7 & 38.9 & 9.2 & 3.8 & 100 \\
\hline \multirow[t]{2}{*}{ Will people cope with increased job variety? } & Count & 35 & 178 & 154 & 45 & 14 & 426 \\
\hline & Column percentage & 8.2 & 41.8 & 36.2 & 10.5 & 3.3 & 100 \\
\hline \multirow[t]{2}{*}{ Will change bring about new challenges in people's jobs? } & Count & 55 & 196 & 127 & 34 & 14 & 426 \\
\hline & Column percentage & 12.9 & 46.0 & 29.8 & 8.0 & 3.3 & 100 \\
\hline
\end{tabular}

DN, definitely not; $N$, no; UC, uncertain; $Y$, yes; YD, yes definitely.

TABLE 8: Organisational structure and policies.

\begin{tabular}{|c|c|c|c|c|c|c|c|}
\hline Question & Response rate & DN & $\mathbf{N}$ & UC & $\mathbf{Y}$ & YD & Total \\
\hline \multirow[t]{2}{*}{ Is the organisation flexible enough to allow any changes? } & Count & 79 & 149 & 132 & 60 & 9 & 429 \\
\hline & Column percentage & 18.4 & 34.7 & 30.8 & 14.0 & 2.1 & 100 \\
\hline \multirow{2}{*}{$\begin{array}{l}\text { Are the organisation's policies flexible enough to accommodate } \\
\text { any changes? }\end{array}$} & Count & 63 & 124 & 183 & 49 & 10 & 429 \\
\hline & Column percentage & 14.7 & 28.9 & 42.7 & 11.4 & 2.3 & 100 \\
\hline \multirow{2}{*}{$\begin{array}{l}\text { Is the structure of the organisation conducive for the } \\
\text { implementation of a PMS? }\end{array}$} & Count & 79 & 100 & 163 & 74 & 11 & 427 \\
\hline & Column percentage & 18.5 & 23.4 & 38.2 & 17.3 & 2.6 & 100 \\
\hline
\end{tabular}

PMS, Performance Management System; DN, definitely not; N, no; UC, uncertain; $Y$, yes; YD, yes definitely.

TABLE 9: Change leadership and interventions.

\begin{tabular}{|c|c|c|c|c|c|c|c|}
\hline Question & Response rate & DN & $\mathbf{N}$ & UC & Y & YD & Total \\
\hline \multirow{2}{*}{$\begin{array}{l}\text { Is the implementation of any change initiative always championed } \\
\text { by the most influential people in the organisation? }\end{array}$} & Count & 123 & 193 & 59 & 42 & 9 & 426 \\
\hline & Column percentage & 28.9 & 45.3 & 13.8 & 9.9 & 2.1 & 100 \\
\hline \multirow[t]{2}{*}{ Is the expected period to make a change always realistic? } & Count & 40 & 165 & 166 & 39 & 16 & 426 \\
\hline & Column percentage & 9.4 & 38.7 & 38.9 & 9.2 & 3.8 & 100 \\
\hline \multirow{2}{*}{$\begin{array}{l}\text { Are the change initiatives within the organisation always well } \\
\text { planned? }\end{array}$} & Count & 35 & 178 & 154 & 45 & 14 & 426 \\
\hline & Column percentage & 8.2 & 41.7 & 36.2 & 10.6 & 3.3 & 100 \\
\hline \multirow{2}{*}{$\begin{array}{l}\text { Are all the components of the business considered in compiling the } \\
\text { change initiatives? }\end{array}$} & e Count & 48 & 198 & 118 & 55 & 6 & 425 \\
\hline & Column percentage & 11.3 & 46.6 & 27.8 & 12.9 & 1.4 & 100 \\
\hline \multirow{2}{*}{$\begin{array}{l}\text { Are the employees who are affected by the change involved in } \\
\text { drafting the change plans? }\end{array}$} & Count & 55 & 196 & 127 & 34 & 14 & 426 \\
\hline & Column percentage & 12.9 & 46.0 & 29.8 & 8.0 & 3.3 & 100 \\
\hline \multirow{2}{*}{$\begin{array}{l}\text { Are the employees committed to the change initiatives in the } \\
\text { organisation? }\end{array}$} & Count & 76 & 130 & 156 & 47 & 14 & 423 \\
\hline & Column percentage & 18.0 & 30.7 & 36.9 & 11.1 & 3.3 & 100 \\
\hline
\end{tabular}

DN, definitely not; N, no; UC, uncertain; $Y$, yes; YD, yes definitely. 
- were likely to focus on improving the current situation rather than pursuing the change process (56\%)

- were unlikely to take the blame when the change process or its elements failed (48.1\%)

- were willing to provide support for the rest of the change process $(63.1 \%)$

\section{Ethical considerations}

All participation was voluntary and participants could withdraw at any stage. The researchers did not ask for personal details and did not know the identity of respondents. This voluntary process did not infringe on the rights of any respondents.

\section{Discussion}

The results showed that employees were not ready for a new PMS. Of primary importance was the fact that many employees did not understand what a PMS was. This basic level of knowledge is required before organisations introduce new systems. It suggests that organisations need to improve communication and training levels before introducing new systems.

The finding that employees felt that top managers did not show any commitment to the change initiatives is significant. Without organisational buy-in and leadership from the top, a new system is unlikely to succeed.
These findings show that the work climate was not conducive for the change process at the time. Most participants argued that:

- people in their respective work units did not encourage each other to support the change process $(68 \%)$

- people did not see the change as positive for their respective work units (59\%)

- the people the organisation selected to act as change agents were not fully trained (54\%)

- there is no counselling available to people who suffer from the emotional effects associated with the change initiative $(64 \%)$.

These intra-personal and inter-personal features would hinder support for the change process and might undermine it. Organisations need adequate preparation, education, communication and leadership to create the positive preconditions for change.

One of the most fundamental aspects for change to be successful is the motivation of employees to change. It reduces resistance to change and ensures greater buy-in from employees. However, it emerged from the data the researchers collected that people were not looking forward to the introduction of a PMS and that a PMS would not benefit them. Of the respondents, $74 \%$ indicated that employees were not committed to achieving the objectives of a PMS.

TABLE 10: Attitudes and feelings about introducing a performance management system.

\begin{tabular}{|c|c|c|c|c|c|c|c|}
\hline Question & Response rate & DN & $\mathbf{N}$ & UC & $\mathbf{Y}$ & YD & Total \\
\hline \multirow[t]{2}{*}{ Will people be committed to achieving the objectives of a PMS? } & Count & 112 & 205 & 54 & 47 & 8 & 426 \\
\hline & Column percentage & 26.3 & 48.1 & 12.7 & 11.0 & 1.9 & 100 \\
\hline \multirow{2}{*}{$\begin{array}{l}\text { Do employees believe that the implementation of a PMS will } \\
\text { improve the performance of the organisation? }\end{array}$} & Count & 120 & 169 & 78 & 46 & 12 & 425 \\
\hline & Column percentage & 28.2 & 39.8 & 18.4 & 10.8 & 2.8 & 100 \\
\hline \multirow{2}{*}{$\begin{array}{l}\text { Do employees believe that the implementation of a PMS will be } \\
\text { beneficial to them? }\end{array}$} & Count & 87 & 190 & 93 & 45 & 11 & 426 \\
\hline & Column percentage & 20.4 & 44.6 & 21.8 & 10.6 & 2.6 & 100 \\
\hline \multirow[t]{2}{*}{ Are people looking forward to the implementation of a PMS? } & Count & 112 & 144 & 105 & 53 & 12 & 426 \\
\hline & Column percentage & 26.3 & 33.8 & 24.7 & 12.4 & 2.8 & 100 \\
\hline \multirow{2}{*}{$\begin{array}{l}\text { Do most people believe that the implementation of a PMS will } \\
\text { have a positive effect on their earnings? }\end{array}$} & Count & 99 & 143 & 125 & 49 & 13 & 429 \\
\hline & Column percentage & 23.1 & 33.3 & 29.1 & 11.4 & 3.1 & 100 \\
\hline \multirow{2}{*}{$\begin{array}{l}\text { Will the implementation of a PMS improve relationships } \\
\text { between staff members and with their supervisors? }\end{array}$} & Count & 47 & 61 & 199 & 114 & 8 & 429 \\
\hline & Column percentage & 11.0 & 14.2 & 46.3 & 26.6 & 1.9 & 100 \\
\hline \multirow{2}{*}{$\begin{array}{l}\text { Is the implementation of a PMS viewed as fair towards } \\
\text { employees? }\end{array}$} & Count & 56 & 196 & 120 & 46 & 11 & 429 \\
\hline & Column percentage & 13.1 & 45.6 & 28.0 & 10.7 & 2.6 & 100 \\
\hline $\begin{array}{l}\text { Is the implementation of a PMS viewed as an additional stress } \\
\text { factor at work? }\end{array}$ & Column percentage & 2.1 & 17.7 & 34.3 & 40.1 & 5.8 & 100 \\
\hline
\end{tabular}

PMS, Performance Management System; DN, definitely not; N, no; UC, uncertain; $Y$, yes; YD, yes definitely.

TABLE 11: The willingness of employees to be part of a change process.

\begin{tabular}{|c|c|c|c|c|c|c|c|}
\hline Question & Response rate & vu & $\mathbf{U}$ & NA & $\mathbf{L}$ & VL & Total \\
\hline \multirow[t]{2}{*}{ Willingly (choose to ) be part of a new change initiative } & Count & 14 & 39 & 34 & 279 & 59 & 425 \\
\hline & Column percentage & 3.3 & 9.2 & 8.0 & 65.6 & 13.9 & 100 \\
\hline \multirow{2}{*}{$\begin{array}{l}\text { Willingly (choose to) change the way you work because of the } \\
\text { change process }\end{array}$} & Count & 9 & 27 & 83 & 241 & 64 & 424 \\
\hline & Column percentage & 2.1 & 6.4 & 19.6 & 56.8 & 15.1 & 100 \\
\hline \multirow{2}{*}{$\begin{array}{l}\text { Willingly (choose to) to focus on improving the current situation } \\
\text { rather than pursuing the change process }\end{array}$} & Count & 7 & 58 & 120 & 201 & 35 & 421 \\
\hline & Column percentage & 1.7 & 13.8 & 28.5 & 47.7 & 8.3 & 100 \\
\hline \multirow{2}{*}{$\begin{array}{l}\text { Willingly (choose to) take the blame when the change process or } \\
\text { elements thereof fail }\end{array}$} & Count & 80 & 125 & 121 & 65 & 35 & 426 \\
\hline & Column percentage & 18.8 & 29.3 & 28.4 & 15.3 & 8.2 & 100 \\
\hline \multirow{2}{*}{$\begin{array}{l}\text { Willingly (choose to) provide support for the remainder of the } \\
\text { change process }\end{array}$} & Count & 13 & 73 & 72 & 181 & 89 & 428 \\
\hline & Column percentage & 3.0 & 17.1 & 16.8 & 42.3 & 20.8 & 100 \\
\hline
\end{tabular}

VU, very unlikely; U, unlikely; NA, not applicable; L, likely; VL, very likely. 
The study also considered the feelings of the employees about the change initiative. Most of the respondents indicated that they did not see the introduction of a PMS as fair to employees. The study found that most of the respondents had a negative perception of a PMS because they see the introduction of a PMS as an additional stress factor at work. Most also did not feel that a new PMS would be different from the previous unsuccessful efforts. The drawbacks and negative experiences of the previous system might have caused this situation.

The findings showed that employees did not have a clear understanding of the change process. In this context, Hale (2004) noted that employees should have a conceptual understanding of what a change initiative entails and how they can benefit from such a new system. Kok (2007) and Van Tonder (2004) echoed this view and contended that, without communication, change cannot happen and employees should understand that communication would enable them to see change as valid and relevant. Lorenzi and Riley (2000) contended that better communication about change initiatives in organisations would ensure continuous dialogue between managers, or supervisors, and subordinates. Werner and Asch (2007) and Kim (2009) supported this view and stated further that dialogue should be open, direct, and respectful, and should use shared change responsibility and new ideas as its basis.

It is clear from the data the researchers collected that employees lacked motivation and that this was because they lacked confidence in the leaders of the organisation. Thach and Thompson (2007), as well as Kelman (2005), emphasised a climate of trust between the leader and the rest of the team because trust brings hope for a better future and makes it much easier to cope with drastic change.

The data the researchers collected showed that the organisation did not encourage employees to make suggestions about introducing a new PMS. Amanto (2009) contended that the best way to involve employees in a change process is by empowering and encouraging them to share and provide new ideas and to make sure that organisations communicate the reasons for the changes well and that all member of groups understand them easily.

The literature the researchers reviewed emphasised the proper planning of the change process, the timing of the introduction, the commitment of employees and leaders as well as consideration of various business components like structure, culture, vision, strategy and mission (Leighton Holdings Limited, 2010; Sparrow, 2008; Su, Baird \& Blair, 2009; Witcher \& Chau, 2008). The researchers identified all of these factors as challenges in this study. They also regarded the period for making the change as unrealistic. It was also clear that the organisation had not planned the change initiative well.

The findings showed that employees did not receive training to cope with their new job requirements and that they would not cope with the increased job variety. The fear of some respondents (58\%), who argued that people would not reach their potential after the organisation introduced the PMS, also supported this. This is quite possible given the absence of adequate training.

The researchers established that the participants were sceptical as to whether introducing a new PMS would improve relationships between staff members and their supervisors. Nelongo (2011) identified poor relationships as one of the main causes of poorly implemented performance management systems because peer groups, with their social structures, elicit more response from employees than the incentives and controls of managers do.

\section{Recommendations}

The researchers make the recommendations that follow.

Because of the lack of knowledge and communication about performance management systems, organisations should manage their stakeholders and conduct a stakeholder impact analysis to address the concerns, challenges and assumptions of the stakeholders before introducing a PMS.

Organisations should develop communication strategies to ensure that the information they provide aligns with the project goals, organisational objectives as well as their visions and missions.

Organisations should indicate the success factors for introducing performance management systems and conduct workshops with the relevant stakeholders to give them, and those concerned with the change processes, a clear understanding of the visions, missions and strategies as well as the outcomes the change processes will achieve.

It is vital for organisations to build a case for change (CFC) for introducing performance management systems. It should be based on preparing the change visions, developing them and understanding the changes.

Organisations should allocate sufficient personnel to serve as change agents and develop them so that they can facilitate the change processes. They should conduct change impact assessments in order to identify risks and the effects of change on people and business, and subsequently develop action plans to manage the effects of change.

Organisations should develop leadership and build capacity to enable and encourage strong change leadership in order to ensure that line managers drive the change initiatives and that the most influential people in the organisations champion them.

Organisations should develop and implement workforcetransitioning plans. They would include identifying skill and competency gaps, training, education, competency feedback, results and developing continuity plans. 


\section{Conclusion}

This study investigated the extent to which employees of a selected organisation were ready for a new PMS. The researchers used a quantitative, questionnaire-based design. A sample of 460 employees completed a change readiness questionnaire to elicit perceptions and opinions about change readiness and the introduction of a new PMS.

The most important principles of successful change management and implementation are communication, involvement and inclusion. This means that people change when they understand the need for change, when they are involved in the process and when they are empowered.

The researchers found that the organisation was not ready to introduce a new PMS and that the employees had negative attitudes and feelings about a new PMS. There is no doubt that the employees were willing to be a part of the change process if the organisation had planned, managed and communicated it to ensure that all employees understood and bought into it.

\section{Acknowledgements Competing interests}

The authors declare that they have no financial or personal relationship(s) that may have inappropriately influenced them when they wrote this paper.

\section{Authors' contributions}

The authors contributed equally to the conceptual development and supervision of this research.

\section{References}

Abdinnour-Helm, S., Lengnick-Hall, M.L., \& Lengnick-Hall, C.A. (2003). Pre implementation attitudes and organizational readiness for implementing an Enterprise Resource Planning system. European Journal of Operational Research, 146(2), 258-273. http://dx.doi.org/10.1016/S0377-2217(02)00548-9

Ainsworth, M., Smith, N., \& Miller, A. (2002). Managing Performance Managing People: Understanding and improving team performance. Australia: Prentice Hall.

Allio, R.J. (2005). Leadership development: Teaching versus learning. Management Decision, 43(7/8), 1071-1077. http://dx.doi.org/10.1108/00251740510610071

Amanto, M. (2009). Change leadership skills. Retrieved December 14, 2010, from http://changeleadership.com/

Amatayakul, M. (2005). EHR? Assess readiness first. Healthcare Financial Management, 59, 112-113.

Armenakis, A.A., \& Harris, S.G. (2002). Crafting a change message to create transformational readiness. Journal of Organisational Change Management, 15, 169-183. http://dx.doi.org/10.1108/09534810210423080

Armstrong, M. (2006). Performance management: Key strategies and practical guidelines. (3rd edn.). London: Kogan Page.

Bacal, R. (2007). Change Management. Retrieved 06 July, 2010, from http://www.work911. com/articles/leadchange.htm

Bennis, W. (2006). Leadership and Change: Becoming a Leader. Retrieved 13 December, 2010, from http://www.nwlink.com/ donclark/leader/leadchg.html

Bridges, W. (2010). Managing Transitions: 3 Guidelines to Successful Change Management. Retrieved 20 September, 2010, from http://www.williambridges.

Bunker, B.B., \& Alban, B.T. (1996). Large Group Interventions: Engaging the Whole System of Rapid Change. San Francisco: Jossey-Bass.

Canterucci, J. (2008). Change, Leadership and Growth. Retrieved 30 January, 2011, from http://www.corpchange.com/Resources/Articles/ LackofChangeReadinessCanCostMillions.aspx

Carnall, C.A. (2007). Managing Change in Organisations. (5th edn.). United Kingdom: Pearson Education Limited.
Cohen, L., Manion, L., \& Morrison, K. (2000). Research Methods in Education. London: Routledge Falmer.

Costello, S.J. (1994). Effective performance management - The business skills express series. New York: McGraw-Hill.

D'Ambrosio, C. (2007). Catalysing change: A turnaround success. Retrieved October 26, 2009, from http://www.isixsigma.com/library/content/c030505a.as

DeCenzo, D.A., \& Robbins, S.P. (2005). Fundamentals of human resource management. (8th edn.). USA: John Wiley \& Sons.

Dixon, R. (2004). The management task. (3rd edn.). New York: Esevier ButterworthHeinemann.

Foxcroft, C. (2005). Developing a psychological measure. In C. Foxcroft \& G. Roodt (Eds.), An introduction to psychological assessment in the South African context. (pp. 46-56). Cape Town: Oxford University Press Southern Africa.

Hale, J. (2004). Performance-based management: What every manager should do to get results. San Francisco: John Wiley \& Sons Ltd.

Hardison, C. (1998). Readiness, action, and resolve for change: Do health care leaders have what it takes? Quality Management Health Care, 6, 44-51. PMid:10178159

Hitchcock, G., \& Hughes, D. (1995). Research and the teacher. (2nd edn.). London: Routledge.

Jacobs, R.W. (1994). Real time strategic change. San Francisco: Berrett-Koehler.

Jones, R.A., Jimmieson, N.L., \& Griffiths, A. (2005). The impact of organisational culture and reshaping capabilities on change implementation success: The mediating role of readiness for change. Journal of Management Studies, 42, 361-386. http:// dx.doi.org/10.1111/j.1467-6486.2005.00500.x

Kaplan, R.S., \& Norton, D.P. (1996). The balance scorecard: Translating strategy into action. Boston: Harvard Business School Press.

Karve, V. (2009). Implementation and change management: Force field analysis. Retrieved September 16, 2010, from http://www.vikramkarve.sulekha.com

Kates, J., Marconi, K., \& Mannle Jr., T.E. (2001). Developing a performance management system for a federal public health programme: The Ryan White management system for a federal public health programme: The Ryan White dx.doi.org/10.1016/S0149-7189(01)00005-2

Kelman, S. (2005). Unleashing change. Washington, DC: The Brookings Institute Press.

Keet, R. (2005). City of Windhoek - Office of the Chief Executive Officer: Draft Strategic Management Report (Revision 2). South Africa: Corporate Renaissance Group.

Kim, P. (2009). A case for performance management for political appointees. Public Personnel Management, 38(4), 1-18.

Kloot, L. (2009). Performance measurement and accountability in the Australian fire service. International Journal of Public Sector Management, 22(2), 128-45. http://dx.doi.org/10.1108/09513550910934538

Kok, L.J. (2007). Practical integrated performance management. Local Government Implementation. South Africa: Louis Jacobus Kok.

Kuhn, M. (2009). Quantitative research. USA: McGraw-Hill Companies, Inc.

Leighton Holdings Limited. (2010). Eastern Distributor Operations and Maintenance. Retrieved June 16, 2011, from www.leighton.com.au/about_us/projects/eastern distributor_motorway_operations_maintena.html/company/6972

Levy, P.S., \& Lemeshow, S. (2011). Sampling of populations: Methods and applications. New Jersey: John Wiley \& Sons.

Lorenzi, N.M., \& Riley, R.T. (2000). Managing change - An overview. Journal or the American Medical Informatics Association, 7(2), 116-124. http://dx.doi. org/10.1136/jamia.2000.0070116, PMid:10730594

Madsen, S.R., Miller, D., \& John, C.R. (2005). Readiness for organisational change: Do organisational commitment and social relationships in the workplace make a difference? Human Resource Development Quarterly, 16, 213-233. http://dx.doi. org/10.1002/hrdq.1134

Munn, P., \& Drever, E. (1995). Using questionnaires in small-scale research: A teacher's guide. Great Britain: SCRE Publication.

Nelongo, J. (2011, 14 February). Effective performance management. New Era Newspaper.

Nickols, F. (2006). Distance consulting: Change management 101. Retrieved June 20, 2009, from http://home.att.net/ nickols/change.htm

O'Connor, E.J., \& Fiol, C.M. (2006). Creating readiness and involvement. Physician Exec, 32, 72-74.

Olve, N., Roy, J., \& Wetter, M. (2004). A practical guide to the balanced scorecard: Performance drivers. England: John Wiley \& Sons Ltd.

Parsons, D. (1984). Employment and manpower surveys: A practitioner's guide. Aldershot: Gower Press.

Plant, T., \& Douglas, J. (2006). The performance management continuum in municipa government organisations. Performance Improvement, 45(1), 43-48. http:// dx.doi.org/10.1002/pfi.2006.4930450109

Poister, T.H. (2003). Measuring performance in public and non-profit organisations. San Francisco: Jossey-Bass.

Robbins, H. (2010). Business coaching and change management. Retrieved September 15, 2010, from http://www.harveyrobbins.com

Robbins, S.P., Odendaal, A., \& Roodt, G. (2003). Organisational behaviour. Global and Southern African perspectives. South Africa: Pearson Education.

Rogan, M. (2002). The Transformation of BP. London: London Business School.

Roodt, G., \& Kinnear, C. (2007). Change Readiness Inventory (CRI) Manual. Johannesburg: Jopie van Rooyen \& Partners SA (Pty) Ltd. 
Salant, P., \& Dillman, D.A. (1994). How to conduct your own survey. John Wiley \& Sons, Inc.

Saunders, M., Lewis, P., \& Thornhill, A. (2003). Research methods for business students. (3rd edn.). England: Pearson Education Limited.

Schepers, J.M. (1992). Toetskonstruksie: Teorie en Praktyk. Johannesburg: Rand Afrikaans University.

Sparrow, P. (2008). Performance management in the UK. In A. Varma, P.S. Budwar \& DeNisi (Eds.), Performance management systems: A global perspective. New York, NY: Routledge.

Stacey, R. (2003). Strategic management and organisational dynamics. Harlow: Pearson Prentice Hall.

Stensgaard, A. (2007). Challenges of Change Leadership. Retrieved December 13, 2010, from http://www.ameinfo.com/60938.html

Stratman, R. (2002). Enterprise resource planning (ERP) competence constructs: Two-stage multi-item scale development and validation. Decision Sciences, 33(4) 601-628. http://dx.doi.org/10.1111/j.1540-5915.2002.tb01658.x

Su, S.X., Baird, K., \& Blair, B. (2009). Employee organizational commitment: The influence of organizational and cultural factors. The International Journa of Human Resource Management, 20(12), 2494-2516. http://dx.doi. org/10.1080/09585190903363813

Swanson, R.A. (1996). Analysis for improving performance: Tools for diagnosing organisations and documenting workplace experience. San Francisco: BerrettKoehler Publishers.

Thach, E., \& Thompson, K.J. (2007). Trading places - Examining leadership competencies between for-profit vs. Public and non-profit leaders. Leadership \& Organisation Development Journal, 28(4), 356-375. http://dx.doi org/10.1108/01437730710752229
Van Rooyen, J. (2007). Change Readiness Inventory (CRI) Manual. Johannesburg: Jopie van Rooyen \& Partners SA (Pty) Ltd.

Van Tonder, C.L. (2004). Organisational change. Theory and practice. Pretoria: Van Schaik Publishers.

Walters, M. (1995). The performance management handbook. London: Institute of Personnel and Development.

Weiner. B.J. (2009). A Theory of organisational readiness for change. Retrieved January 25, 2011, from http://www.implementationscience.com/content/4/1/67

Weiner, B.J., Amick, H., \& Lee, S.Y. (2008). Conceptualisation and measurement of organisational readiness for change: A review of the literature in health services research and other fields. Retrieved January 30, 2011, from http://www. implementationscience.com/content/4/1/67

Weiss, T.B., \& Hartle, F. (1997). Reengineering performance management: Breakthrough in achieving strategy through People. Florida: St Lucie Press.

Werner, R.M., \& Asch, D.A. (2007). Clinical concerns about clinical performance measurement. Annals of Family Medicine, 5, 159-163. http://dx.doi.org/10.1370/ afm.645, PMid:17389541

Williams, R.S. (2002). Managing employee performance - Design and implementation in organisations. Australia: Thomson Learning.

Williams, Q.W. (2006). Implementing performance management at local government level in South Africa: A case study on the impact of organisational culture. Unpublished Master's thesis, Rhodes University, South Africa.

Witcher, B.J., \& Chau, V.S. (2008). Strategic and performance management balanced scorecards at EDF Energy and Tesco. Strategic Change, n.p.

WorldatWork Journal. (2006). Society of Certified Professionals Performance Management: Strategy, Design and Implementation. Course GR5. Scottsdale. 